\title{
Wpływ charakterystyk spawalniczych łuku na właściwości napoin
}

\author{
The influence of the characteristics of welding arc \\ on the properties of the padding welds
}

\section{Streszczenie}

W pracy przedstawiono wyniki badań wpływu charakterystyki łuku spawalniczego na właściwości napoin wykonanych drutem rdzeniowym samoosłonowym. Proces napawania prowadzony był z użyciem łuku zwarciowego, mieszanego oraz łuku impulsowego. Otrzymane napoiny charakteryzowały się dużymi różnicami w uzyskanej twardości rzędu nawet 200HV10. Charakterystyka łuku wpłynęła również na stopień wymieszania napoiny z materiałem podłoża oraz samą strukturę napoiny. Najkorzystniejsze właściwości napoiny zanotowano dla łuku impulsowego.

Słowa kluczowe: napawanie; łuk impulsowy; stopień wymieszania

\begin{abstract}
The paper presents results of research on cladding made with different characteristics of welding arc and their effect on the properties of the hardfacing made with self shield cored wire. Hardfacing was done with short circuit characteristic, mixed and with pulse current. The obtained deposits were varied in hardness values up to $200 \mathrm{HV} 10$. It was observed that characteristic of welding arc has large influence on the dilution rate and the structures of the deposits. The best properties of the deposits were noted to the pulsed arc current.
\end{abstract}

Keywords: hardfacing; pulsed arc; dilution rate

\section{Wstęp}

Uzyskanie najwyższych parametrów użytkowych materiałów wymaga w wielu przypadkach poprawy właściwości warstwy wierzchniej części maszyn i urządzeń z wykorzystaniem technik nanoszenia powłok. Jednym z bardziej ekonomicznych sposobów poprawy właściwości powierzchni części maszyn i urządzeń jest proces napawania. Do napawania stosuje się różne techniki spawalnicze takie jak np. napawanie metodą MAG, metodą TIG czy też napawanie łukiem krytym. Różnice w tych technikach są znaczące, a najważniejsze z nich to wydajność napawania, ilość wprowadzonego ciepła, stopień wymieszania materiału rodzimego z napoiną. Czynniki te mają istotny wpływ na jakość uzyskiwanych napoin oraz na ekonomikę procesu napawania. Równie ważny jest rodzaj łuku spawalniczego jaki został wykorzystany przy procesie napawania. Obecnie jednym z głównych procesów spawalniczych stosowanych w celu kształtowania powierzchni metali jest napawaniem drutami rdzeniowymi. Proces ten, dzięki dużej wydajności oraz szerokim możliwościom kształtowania składu chemicznego drutu umożliwia efektywne uzyskiwanie powłok o dużej twardości i odporności na zużywanie $[1 \div 5]$. W katalogach materiałowych, producenci drutów rdzeniowych podają szerokie zakresy parametrów prądowych procesu napawania, dzięki czemu możliwe jest zastosowanie różnych charakterystyk łuku spawalniczego. Celem prezentowanych badań było porównanie właściwości napoin wykonanych drutem rdzeniowym samoosłonowym, przy użyciu różnych warunków stapiania drutu, w tym z wykorzystaniem łuku impulsowego. Każdy z analizowanych $w$ pracy rodzajów łuku tzn. łuk zwarciowy, mieszany i impulsowy, poprzez odmienny sposób oddziaływania źródła ciepła na materiał wpływa na podstawowe właściwości uzyskiwanych napoin, takich jak: wymiary geometryczne napoiny, stopień wymieszania z materiałem bazowym czy uzyskiwane twardości.

\section{Metodyka badań}

Jako materiał podstawowy do układania napoin zastosowano stal konstrukcyjną S235JR o grubości $10 \mathrm{~mm}$. Do wykonania napoin posłużono się drutem rdzeniowym samoosłonowym MOST F-64 o średnicy 1,2 mm i składzie chemicznym przedstawionym $\mathrm{w}$ tablicy $\mathrm{I}$.

Mgr inż. Krzysztof Makles, dr inż. Marek Gucwa - Politechnika Częstochowska.

Autor korespondencyjny/Corresponding author: krzymakles@gmail.com 
Tablica I. Skład chemiczny drutu rdzeniowego MOST F-64 Table I. Chemical composition of self shielded cored wire MOST F-64

\begin{tabular}{|c|c|c|c|c|}
\hline C [\%] & Cr [\%] & V [\%] & W [\%] & Fe [\%] \\
\hline 3,8 & 22 & 0,8 & 0,8 & reszta \\
\hline
\end{tabular}

Źródło prądu wykorzystane do badań stanowił programowalny punktowo zasilacz z przemianą częstotliwości po stronie wtórnej GLC 353 Quinto Profi firmy CLOOS. Do rejestracji wartości prądu spawania oraz napięcia łuku wykorzystano układ przetworników prądu i napięcia oraz przetwornik analogowo-cyfrowy USB 6251 firmy National Instruments. Parametry łuku impulsowego wyznaczono w oparciu o algorytm przedstawiony w pracy [6], przyjmując dodatkowo warunek utrzymania energii impulsu na poziomie $E_{i}=50 \mathrm{~J}[7]$. Uzyskane napoiny zostały poddane badaniom metalograficznym z wykorzystaniem mikroskopu optycznego Olympus GX51.

\section{Wyniki badań}

Na rysunku 1 zaprezentowano charakterystyki spawalnicze łuku dla każdej z wykonanych napoin. Dobrany zakres użytkowy parametrów podczas napawania umożliwił zmianę charakteru przepływu metalu dodatkowego do jeziorka przy zachowaniu zbliżonej średniej wartości prądu. Zarejestrowane przebiegi napięcia i prądu napawania umożliwiły analizę stabilności procesu oraz określenie energii liniowej na podstawie równania [8]:

$$
E_{l}=\eta \cdot \frac{1}{l_{w}} \cdot \int_{t_{s 1}}^{t_{s 2}}\left(I_{S}(t) \cdot U_{s}(t)\right) d t
$$

gdzie:

$I_{w}[\mathrm{~cm}]$ - długość wykonanej napoiny

$\mathrm{I}_{\mathrm{s}}(\mathrm{t})[\mathrm{A}]$ - wartość chwilowa prądu spawania

$\mathrm{U}_{\mathrm{s}}(\mathrm{t})[\mathrm{V}]$ - wartość chwilowa napięcia łuku

$t_{\mathrm{s} 2}$ i $t_{\mathrm{s} 1}$ - czas zakończenia oraz rozpoczęcia spawania

$\eta$ - współczynnik sprawności cieplnej łuku (przyjęto 0,8)

Na rysunku 2 przedstawiono widok z badań makroskopowych badanych napoin. Wszystkie próbki były trawione Nitalem i następnie określono na przygotowanych w ten sposób powierzchniach podstawowe właściwości geometryczne uzyskanych napoin. Wyniki pomiarów szerokość napoiny $-\mathrm{a}$, wysokości $-\mathrm{H}_{\mathrm{N}}$ głębokości wtopienia $-\mathrm{H}_{\mathrm{w}}$ oraz stopnia wymieszania materiału rodzimego $\mathrm{z}$ napo iną $-U_{p}$, przedstawiono $w$ tablicy III.
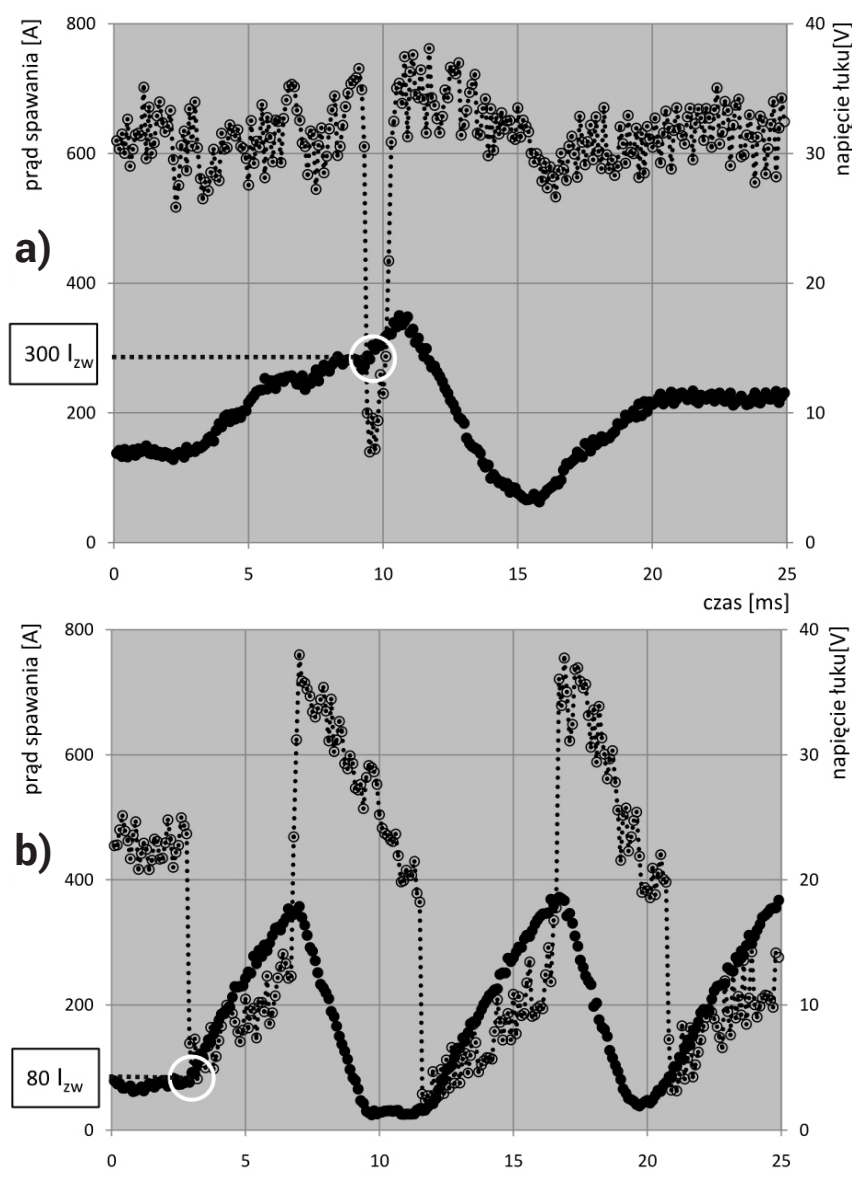

czas [ms]

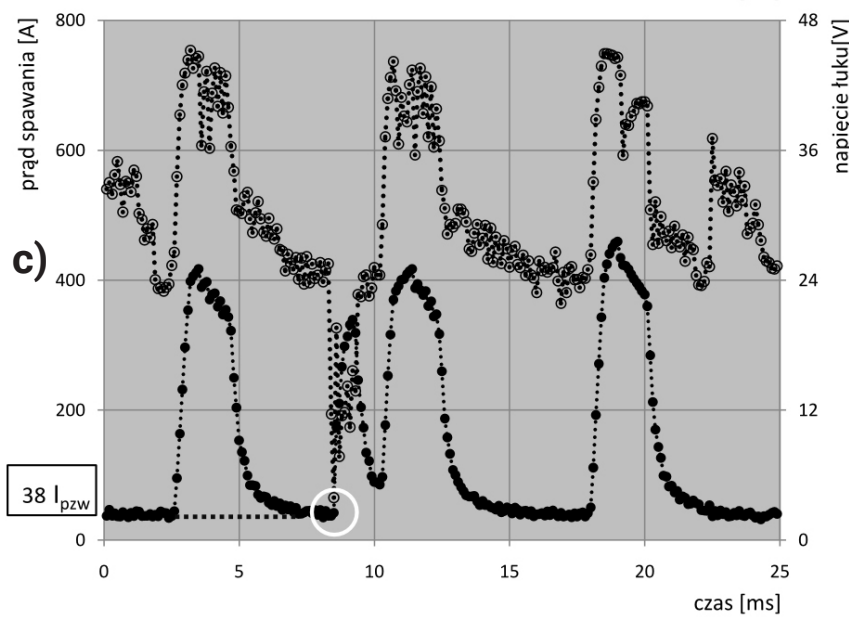

Rys. 1. Wpływ rodzaju łuku na zaobserwowany prąd zwarcia: a) łuk mieszany, b) łuk zwarciowy, c) łuk impulsowy

Fig. 1. Effect of arc modes on experimentally observed short - circuit current: a) globular transfer, b) short circuit transfer, c) pulsed arc

Tablica II. Zestawienie parametrów napawania

Table II. Comparison of hardfacing parameters

\begin{tabular}{|c|c|c|c|c|c|}
\hline \multicolumn{5}{|c|}{ Prędkość napawania [cm/min] } & 25 \\
\hline \multicolumn{5}{|c|}{ Odległość dyszy stykowej od materiału napawanego [mm] } & 15 \\
\hline \multicolumn{5}{|c|}{ Kąt ustawienia palnika } & $90^{\circ}$ \\
\hline Nr próbki & Rodzaj łuku & Napięcie [V] & Natężenie [A] & $\begin{array}{l}\text { Prędkość posuwu drutu } \\
\text { elektrodowego }[\mathrm{m} / \mathrm{min}]\end{array}$ & Energia liniowa $[\mathrm{kJ} / \mathrm{cm}]$ \\
\hline 1 & mieszany & 31,5 & 178 & 7,1 & 10,8 \\
\hline 2 & zwarciowy & 16,7 & 182 & 6,2 & 6,1 \\
\hline \multirow{3}{*}{3} & \multirow{3}{*}{ impulsowy } & 29,1 & 175 & 8,3 & 10,8 \\
\hline & & $\mathrm{U}_{\mathrm{i}}[\mathrm{V}]$ & $\mathbf{f}_{\mathrm{i}}[\mathrm{Hz}]$ & $t_{i}[\mathrm{~ms}]$ & $\mathrm{I}_{\mathrm{b}}[\mathrm{A}]$ \\
\hline & & 40 & 130 & 2,1 & 38 \\
\hline
\end{tabular}


Tablica III. Zmierzone właściwości napoin

Table III. The measured properties of the padding welds

\begin{tabular}{|c|c|c|c|c|c|c|}
\hline \multirow[b]{2}{*}{ Napoina } & \multicolumn{4}{|c|}{ Zmierzone wielkości geometryczne napoiny } & \multirow{2}{*}{$\begin{array}{c}\text { Twardość } \\
\text { HV10 }\end{array}$} & \multirow{2}{*}{$\begin{array}{c}\text { SDAS } \\
\mu \mathrm{m}\end{array}$} \\
\hline & $\mathrm{U}_{\mathrm{p}}[\%]$ & $\mathrm{a}[\mathrm{mm}]$ & $\mathrm{H}_{\mathrm{N}}[\mathrm{mm}]$ & $\mathrm{H}_{\mathrm{w}}[\mathrm{mm}]$ & & \\
\hline 1 & 28 & 10,96 & 3,38 & 1,67 & 634 & 9,91 \\
\hline 2 & 17 & 6,51 & 4,47 & 1,38 & 749 & 5,60 \\
\hline 3 & 17 & 10,75 & 3,87 & 1,08 & 843 & 4,44 \\
\hline
\end{tabular}
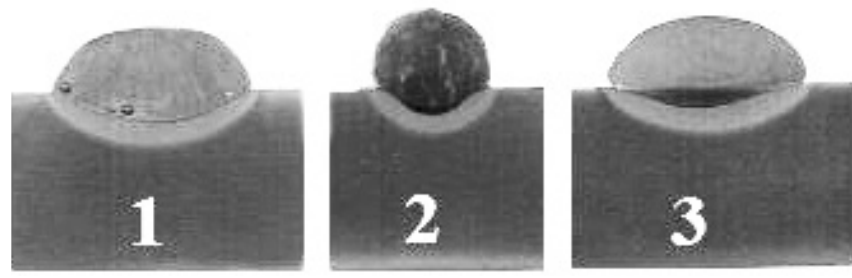

Rys. 2. Makro wykonanych napoin

Fig. 2. The view of the obtained padding welds

Stopień wymieszania materiału rodzimego z napoiną $\left(U_{p}\right)$ określono w oparciu o pomiar wielkości powierzchni nadlewu napoiny $\left(F_{N}\right)$ oraz powierzchni wtopienia $\left(F_{w}\right)$

$$
U_{p}=F_{w} /\left(F_{N}+F_{w}\right) \times 100 \%
$$

$\mathrm{Na}$ kolejnych rysunkach $3 \div 5$ przedstawiono strukturę uzyskanych napoin. Wszystkie napoiny były trawione odczynnikiem Mi19Fe.
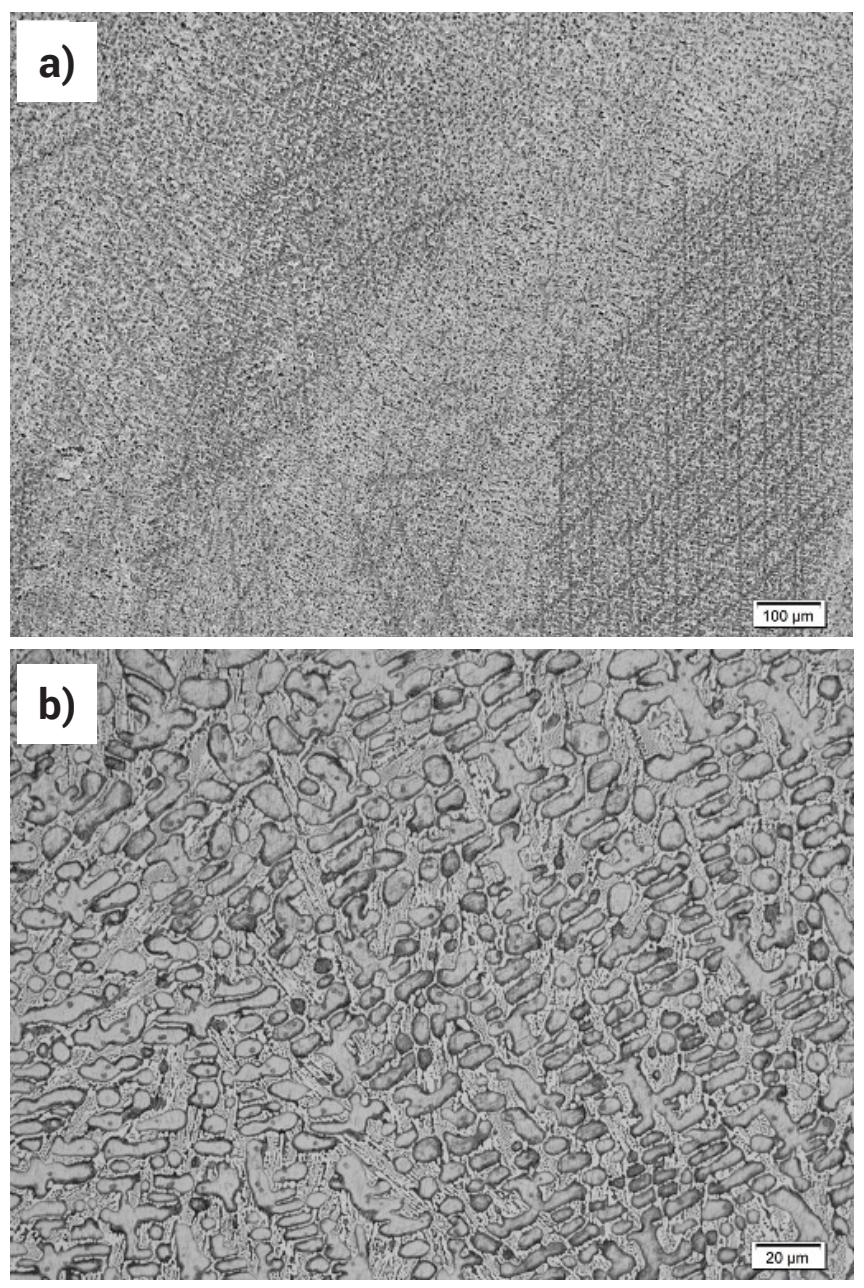

Rys. 3. Struktura napoiny numer 1 - powiększenie a) $x 100$, b) $x 500$

Fig. 3. The structure of deposit number 1 - magnification a) $\times 100$, b) $x 500$

\section{Analiza uzyskanych wyników}

Badając przekroje uzyskanych napoin, stwierdzono niewielką porowatość w każdej z badanych próbek. Niezgodność nie występowała jednak w całej objętości wykonanych napoin, lecz na kilku z wielu analizowanych przekrojów (rys. 2). Powodem pojawienia się przypadków porowatości może być szybki proces krystalizacji i związane z tym problemy z odgazowaniem ciekłego jeziorka w przypadku napawania drutem rdzeniowym samoosłonowym. Kolejnym powodem występowania porowatości mogą być liczne odpryski, jakie towarzyszyły procesowi napawania, zaburzające pracę łuku spawalniczego i w efekcie wytworzenie skutecznej osłony gazowej. W analizowanych strukturach napoin można zaobserwować dendrytyczny charakter krystalizacji bez wyraźnego wydzielenia się węglików chromu, wanadu czy wolframu, jak wskazywałby na to skład chemiczny użytego drutu rdzeniowego (tabl. I). Nierównowagowy proces krystalizacji spowodował przejście węglików
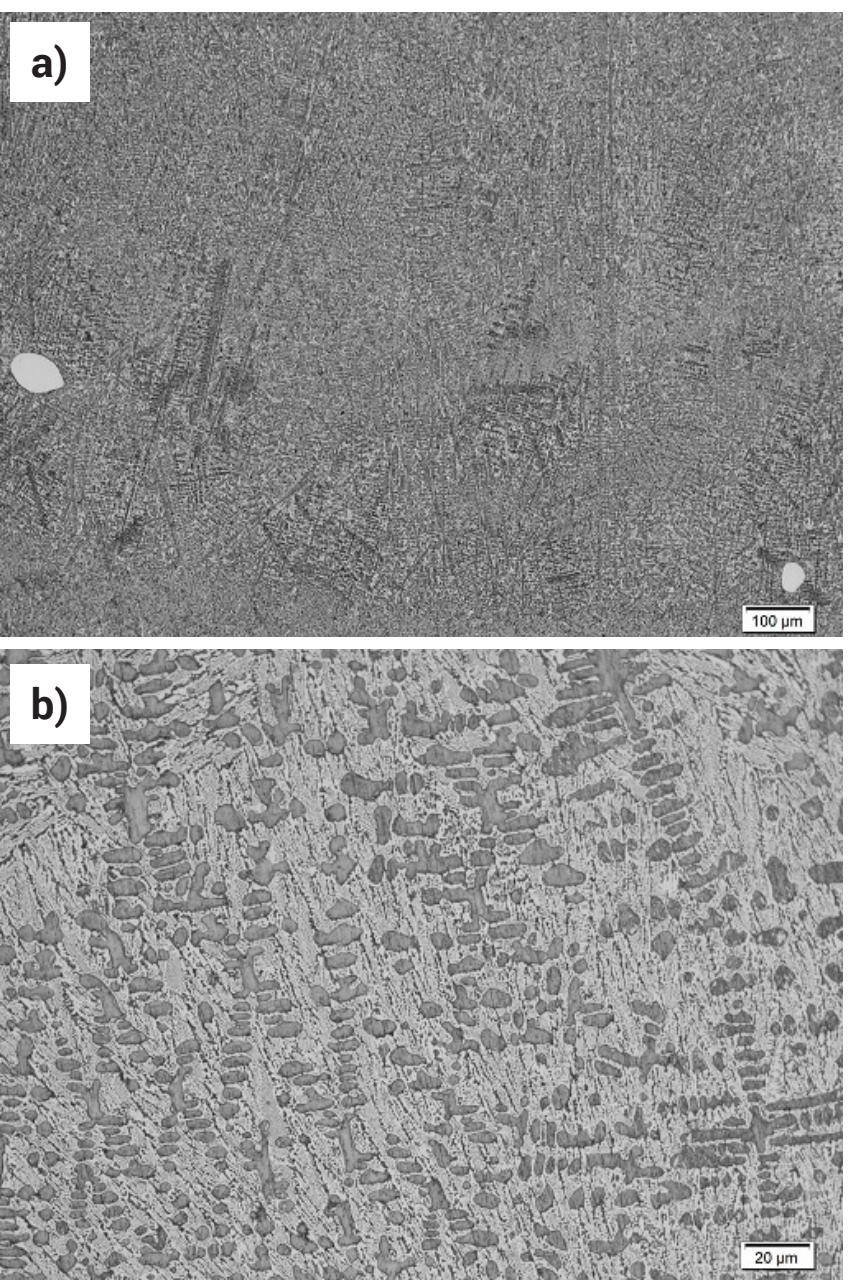

Rys. 4. Struktura napoiny numer 2 - powiększenie a) $x 100$, b) $\times 500$

Fig. 4. The structure of deposit number 2 - magnification a) $x 100$, b) $x 500$ 

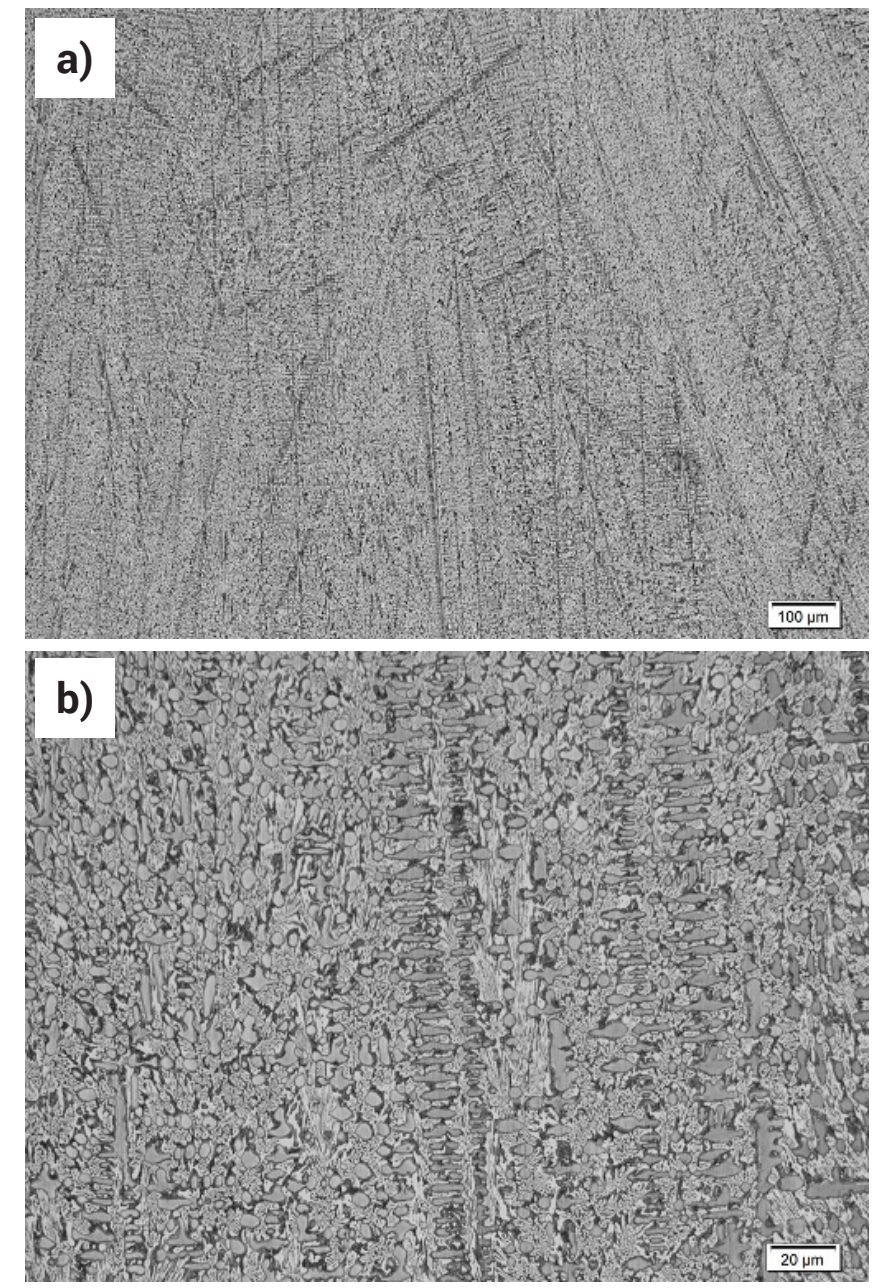

Rys. 5. Struktura napoiny numer $3-$ powiększenie a) $x 100$, b) $x 500$

Fig. 5. The structure of deposit number 3 - magnification a) x100, b) $\times 500$

do roztworu i wzbogacenie w węgiel eutektyki w przestrzeniach międzydendrytycznych (rys. $3 \div 5$ ). Na analizowanych rysunkach można zauważyć wzrost stopnia rozdrobnienia struktury dendrytycznej wyrażonej poprzez odległość między wtórnymi ramionami dendrytów SDAS (tabl. III). SDAS (Secondary Dendrite Arm Spacing) jest parametrem, który może opisywać stopień rozdrobnienia struktury i wskazywać na stopień segregacji składników stopowych oraz ich wpływ na właściwości badanego stopu [9]. Rozdrobnienie struktury dendrytycznej potwierdzone przez SADS przekłada się na zmiany w twardości badanych napoin. W tablicy III przedstawiono średnie zmierzone twardości, które w zależności od rodzaju łuku spawalniczego wykazują między sobą różnice rzędu 200 HV10. Zastosowanie łuku impulsowego pozwoliło na największe rozdrobnienie struktury oraz uzyskanie największej twardości.

\section{Analiza charakterystyk spawalniczych łuku}

Wysoką stabilność procesu oraz niewielki rozprysk uzyskano stosując napawanie łukiem zwarciowym przy sztywnej charakterystyce stałonapięciowej źródła z wykorzystaniem elektronicznego dławika, regulując szybkość narastania prądu $\mathrm{dl} / \mathrm{dt}$ przy zwarciu materiału rodzimego i drutu elektrodowego kroplą ciekłego metalu na poziomie $70 \mathrm{~A} \cdot \mathrm{ms}^{-1}$ (rys. 1b). Przez podwyższenie charakterystyki zewnętrznej zasilacza, obszar pracy łuku dla próbki 1 przesunięto w zakres kroplowego transportu metalu (rys. 1a). Znaczne obniżenie częstotliwości zwarć oraz wysoka wartość napięcia łuku spowodowały zwiększenie ciepła generowanego przez łuk, umożliwiając zwiększenie prędkości posuwu drutu elektrodowego. Proces charakteryzował się rozpryskiem w postaci pojedynczych dużych kropli o średnicy ok. $3 \mathrm{~mm}$. Fakt ten sprawia, że realizowane napawanie trudno jest uznać za stabilne. Prawdopodobną przyczyną powstawania takiej postaci rozprysku jest niekorzystny skład osłony gazowej łuku, przy której zachodzi transport globularny z silnym odpychaniem kropli ciekłego metalu [10]. Inną przyczyną może być znaczna wartość siły elektromagnetycznej w chwili kontaktu kropli z jeziorkiem spawalniczym. Ponieważ do zwarć dochodzi przy wysokiej wartości prądu, bliskiej $300 \mathrm{~A}$, kropla może zostać w wyniku intensywnego zaciskania przewężenia odrzucona od jeziorka z siłą większą niż $10^{-1} \mathrm{~N}$ [11]. Dalsze podwyższenie napięcia znacznie pogarsza stabilność palenia się łuku oraz zwiększa intensywność rozprysku. Przy wykorzystaniu łuku impulsowego, niski prąd bazowy płynący w chwili występowania zwarcia umożliwia łagodniejsze wciągniecie kropli przez siły od napięcia powierzchniowego (rys. 1c), przez co rozprysk jest wyraźnie mniejszy niż przy parametrach stosowanych dla próbki 1. Na podstawie analizy zmian odchyleń wartości amplitudy prądu i napięcia łuku impulsowego należy jednak sądzić, że zastosowana częstotliwość impulsowania jest za wysoka w stosunku do częstotliwości odrywania kropli. Powoduje to znaczne drgania jeziorka ciekłego metalu, co na przebiegach wartości rzeczywistych spawania objawia się fluktuacjami napięcia bazowego (rys. 1c). Dokładna analiza zjawisk zachodzących w łuku będzie możliwa przy zastosowaniu szybkiej fotografii przestrzeni łukowej, co będzie stanowić przedmiot dalszych badań autorów.

\section{Podsumowanie}

Napoina wykonana łukiem zwarciowym o najmniejszej energii liniowej napawania charakteryzowała się takim samym stopniem wymieszania jak napoina wykonana łukiem impulsowym, lecz różnica w twardości sięga prawie 100 HV10. $\mathrm{Na}$ podstawie przeprowadzonych analiz strukturalnych oraz SDAS należy stwierdzić, że najkorzystniejsze własności użytkowe są uzyskiwane z wykorzystaniem impulsowej pracy zasilacza. Zbliżona energia liniowa spawania w przypadku próbek numer 1 i 3 skutkowała uzyskaniem napoin o podobnych wymiarach geometrycznych, ale znacznych różnicach w stopniu wymieszania napoiny z materiałem podstawowym, strukturze oraz twardości. Istnieje zatem możliwość wpływania na właściwości nakładanych warstw wykonanych drutem rdzeniowym samoosłonowym przy zachowaniu zbliżonych wartości energii linowych procesu oraz przy zastosowaniu różnych charakterystyk łuku spawalniczego. 


\section{Literatura}

[1] R. Bęczkowski, M. Gucwa: Wpływ parametrów napawania drutem z rdzeniem metalicznym na wydajność procesu i parametry geometryczne ściegu, Przegląd Spawalnictwa ,vol. 88 nr 5, s. 49-52, 2016.

[2] M. Gucwa, R. Bęczkowski: Możliwość zastosowania napawania drutem rdzeniowym z zastosowaniem prądu pulsującego, Przegląd Spawalnictwa, vol. 87, nr 10, s. 13-16, 2015.

[3] M. Gucwa, J. Winczek, R. Bęczkowski, M. Dośpiał: Structure and Properties of Coatings Made with Self Shielded Cored Wire, Archives Of Foundry Engineering, vol. 16, nr 3, p.39-42, 2016.

[4] M. Gucwa, J. Winczek: The Properties of High Chromium Hardfacings Made with Using Pulsed Arc, Archives Of Foundry Engineering, vol. 15, nr 1, p.37-40, 2015

[5] R. Bęczkowski, M. Gucwa, J. Wróbel, A. Kulawik: The Impact of the Bead Width on the Properties of the Anti-Abrasion Surfacing Weld, AIP Conference Proceedings 1738, 480095 (2016); http://doi.org/10.1063/1.4952331
[6] K. Kudła: Algorytm doboru parametrów spawania impulsowego w osłonie gazów ochronnych, Przegląd Spawalnictwa, vol. 76, nr 5-7, s.94-96, 2004.

[7] I. E. French, M. R. Bosworth: A Comparison of Pulsed and Conventional Welding with Basic Flux Cored and Metal Cored Welding Wires, Welding Research Supplement, vol. 74, nr 6, p.197-205, 1995.

[8] R. Kensik: Ocena energii liniowej w procesach MIG/MAG, Przegląd Spawalnictwa, vol. 78, nr 9-10, s.5-8, 2006.

[9] S. Seifeddine, E. Sjölander, T. Bogdanoff: On the Role of Copper and Cooling Rates on the Microstructure, Defect Formations and Mechanical Properties of Al-Si-Mg Alloys, Materials Sciences and Applications, 2013, 4, 171-178, 2013

[10] J. F. Lancaster. The Physics of Welding, Pergamon, 1986.

[11] J. C. Amson: Lorentz force in the molten tip of an arc electrode, British Journal of Applied Physics, vol. 16, nr 8, p.1169-1179, 1965.

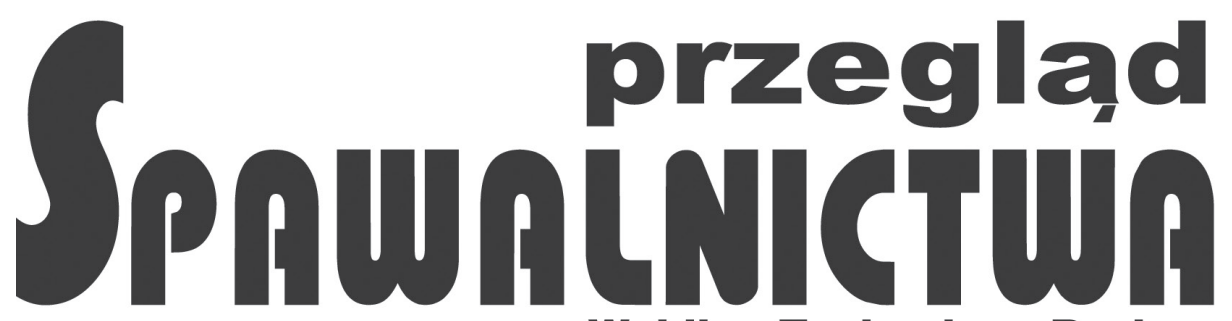

Welding Technology Review
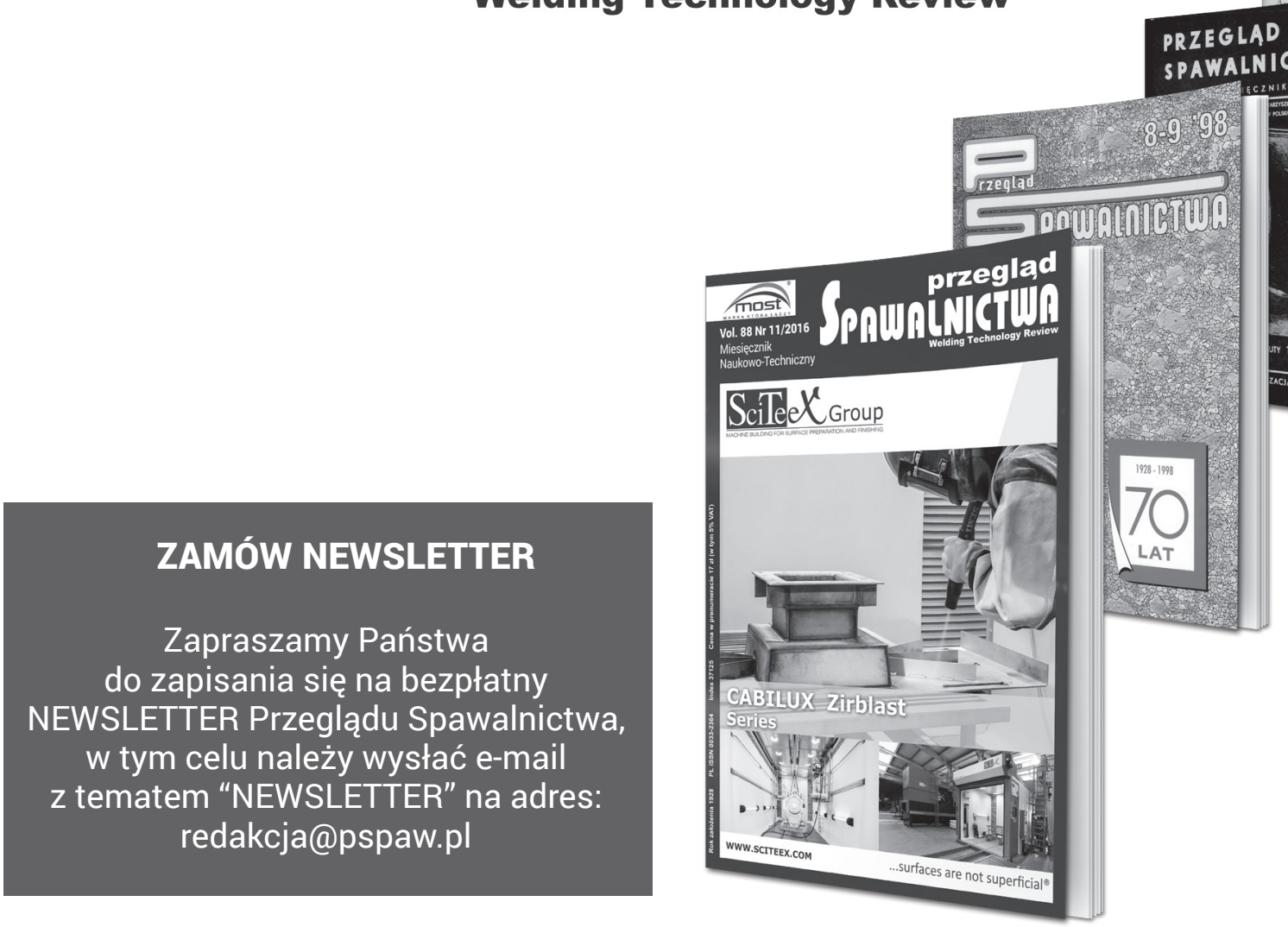